EFCC

3,1

2

Received 27 January 2021

Revised 6 March 2021 Accepted 6 March 2021

\section{Gender in the nationally determined contributions of African countries: a way forward for effective implementation of adaptation and mitigation strategies}

\author{
Charlotte Remteng, Johnson Nkem, Linus Mofor and \\ James Murombedzi \\ United Nations Economic Commission for Africa, Addis Ababa, Ethiopia
}

\begin{abstract}
Purpose - This paper aims to provide an analysis of gender strategies in the planning, programmes towards the implementation of Africa's Nationally Determined Contributions (NDCs). It involved the identification and disaggregation of climate risks on women key climate affected sectors (water, energy, agriculture, health, energy).

Design/methodology/approach - This involves review of vast scholarly and academic research, to establishment of linkages and interlinkages between the risks. A diagnostic analysis was done on the NDCs to understand the orientation of gender considerations in the NDCs of African countries, and then an assessment on emerging opportunities and empowerment of women to address climate change was carried out as an undetachable component of gender considerations.

Findings - Poverty, cultural barriers and inequality, climatic risks such as floods, occurrence of infectious diseases and water scarcity create life threatening situations for women as well as their livelihood Analysis on the NDCs (and INDCs) of all African countries show that over $85 \%$ of actions reference gender. At the regional level West Africa has the highest gender actions in their NDCs (41\%), East Africa 25\%, Southern Africa 15\%, Central Africa 8\% and North Africa 6\%. The coping responses of women, their knowledge about the environment and the environmental services they offer, provide great opportunities for them in the climate change scenario which is seldom spoken about. Empowerment of women by providing access to Information, education, training; sensitization on various facets of climate change; the risks, consequences, possible sustainable solutions (Adaptation and mitigation) and their basic rights especially with regards to land and ownership is necessary, and can help reduce the climatic risks they face.

Research limitations/implications - The limitation of this study was time constraint as the research was done during my fellowship at the United Nations Economic Commission for Africa which was a short period in relation to the fact that the authors were assigned to other duties.

Practical implications - Though most African countries are making an effort towards gender integration in their NDCs, they need to carry out systematic gender analysis; collecting and using sex-
\end{abstract}

(C) Charlotte Remteng, Johnson Nkem, Linus Mofor and James Murombedzi. Published in Ecofeminism and Climate Change. Published by Emerald Publishing Limited. This article is published under the Creative Commons Attribution (CC BY 4.0) licence. Anyone may reproduce, distribute, translate and create derivative works of this article (for both commercial and non-commercial purposes), subject to full attribution to the original publication and authors. The full terms of this licence maybe seen at http:// creativecommons.org/licences/by/4.0/legalcode
Ecofeminism and Climate Change Vol. 3 No. 1, 2022 pp. 2-22

Emerald Publishing Limited e-ISSN: 2633-4070 p-ISSN: $2633-4062$ DOI 10.1108/EFCC-01-2021-0001 
disaggregated data; establishing gender-sensitive benchmarks and indicators; and developing practical tools to support increased attention to gender perspectives.

Social implications - Climate change is a serious threat to humanity and views from mostly those affected indicates that there is still a big disconnect between the ambitious agendas set by various stakeholders involved (International organizations, governments and regional organizations), and the real grassroots initiatives, actions and programs being implemented in the ground. There is also inarguably increasing evidence that climate change is amplifying gender inequality, the vulnerability of women and children; consequently, a serious barrier to the achievement of the Paris Agreement, UN 2030 Sustainable development goals, the 2063 Africa Union Agenda.

Originality/value - Though there exist many research papers on climate and gender and also on NDCs, creating a link between gender risks and climate policies, strategies and programs gives the issue of gender and climate change "high importance". An integrated approach on identifying the risks makes policies coherent.

Keywords Gender, Climate change, Nationally determined contributions

Paper type Literature review

\section{Introduction}

Climate change no doubt poses as one of the most overwhelming challenges the world is currently facing. Zukang (2008) points out that it is already too late to be able to fully stop climate change due to its scale and momentum. However, there is no doubt that much can still be done to curb climate change and prevent its impacts on economic and social development. Africa is highly vulnerable and greatly affected by the impacts of climate change (Niang et al., 2014; Porter et al., 2014), though it has contributed so little to the causes of climate change as reiterated by African countries in their Nationally Determined Contributions (NDCs). Climate change is going to disrupt Africa's development, which is still at its early stages, especially taking into cognizance that rain-fed agriculture constitutes the backbone of most of its economies. More importantly, Africa lacks the finance, capacity and technological knowhow to adequately respond to the enormity of climate change impacts in the continent (Mwebaza and Kotzé, 2009). Climate change did pose a threat to Africa's attainment of the Millennium Development Goals (MDGs), and continue to pose a threat to the attainment of the UN 2030 Sustainable Development Goals (SDGs) and the African Union's Agenda 2063 (UNECA, AU, AFDB, UNDP, 2016).

While climate change affects everyone, it poses specific risks to differentiated social groups making them highly vulnerable to the effects of climate change (Nazrul Islam and Winkel, 2017). In their NDCs, most African countries refer to children, youths, the elderly, people with disabilities, women and environmental refugees as part of the vulnerable group to climate change. Gender is a key consideration in addressing climate change because the impacts of climate change are differentiated by gender. Women commonly face higher risks and greater burdens from the impacts of climate change especially in situations of poverty, and the majority of the world's poor are women (UNFCCC, 2018). Looking at primary impacts of climate change on women, global research indicates that women and children are 14 times more likely to die or be injured than men due to a disaster (Neumayer and Plumper, 2007). Other impacts include loss of economic opportunities resulting from their dependence on natural resources, agriculture. Increase in workloads such as cartering for the sick after climate-disaster related diseases outbreak (such as waterborne diseases, physical injuries from floods) and domestic chores such as fetching fuelwood and water (UN Women, 2014a, 2014b). After the occurrence of natural disasters, women are usually expose to physical and sexual abuse, early marriages as the scrambling for depleting resources and commodities increases. Displacement and migration can lead to an 
EFCC

3,1

increase violence, rape, harassment and discrimination due to over-crowded and unsafe living conditions in evacuation centres, temporary housing and shelters (Goh, A.H.X, 2012; UN Women, 2013; Davis et al., 2005).

Much progress has been made towards integrating gender considerations into climate negotiations, climate planning and climate action, as demonstrated by the efforts from the adoption and implementation of the United Nations Framework Convention on Climate Change (UNFCCC), Lima Work Program on Gender (2014, $\mathrm{FCCC} / \mathrm{CP} / 2014 / 10 /$ Add.3, Decision 18/CP.20) and the gender equality considerations in the recent UNFCCC Paris Agreement (2015, FCCC/CP/2015/L.9/Rev.1), the Sustainable Development Goals (SDGs). Addressing gender issues and achieving equality can generate benefits for both climate mitigation and adaptation, and contribute to sustainable development especially in key sectors of development such as agriculture and water resources management. A study carried by McKinsey global institute revealed that $\$ 12$ tn could be added to global GDP by 2025 by advancing women's equality (McKinsey Global Institute, 2015). In Africa, eliminating gender inequality and empowering women could raise the productive potential of one billion Africans, delivering a huge boost to the continent's development potential (African Development Bank Group, 2015).

Gender equality still remains a challenge for African countries, which pose as a serious hindrance to the effectiveness of adaptation and mitigation strategies. This paper carries out an analysis to facilitate the integration of gender related issues into climate change policies and planning towards the implementation of Africa's NDCs. The first objective is to critically look at the risks women face in key climate change sectors, by identifying their exposure and vulnerability, to give proper insight into elucidations for gender considerations in the NDCs. The second objective is a diagnosis analysis of NDC of Africa countries, which gives an overall take on the continents' gender-responsiveness and preparedness to climate change at regional and sub regional levels. And the third objective exploits the opportunities for empowerment of women in the climate change scenario to give proper orientation for policy recommendations.

\section{Literature review}

\subsection{Climate change and vulnerability}

The IPCC characterizes vulnerability to climate change as a function of a system's exposure and sensitivity to climatic stimuli and its capacity to adapt to adverse effects (IPCC, 2007). Thus, adaptation and mitigation actions are critical to eliminate or reduce the vulnerability of systems to the impacts of climate change. the issue of vulnerability to climate change varies with regions countries, and among different societal groups. Intergovernmental Panel on Climate Change (IPCC) made high confidence conclusions that developing countries will be more vulnerable to climate change than developed countries" (IPCC, 2001a, p. 916).

Children are at greatest risk of injury, disability and death caused by the impacts of climate change because they are less equipped physically, mentally and emotionally to cope with life-threatening conditions (World Vision, 2018). Food insecurity, malnutrition, diarrheal disease, vector-borne diseases, malaria and respiratory diseases, which are the highest causes of mortality among children will be exacerbated by climate change with children living in developing countries facing the greatest risks because of poverty, which limits ability to respond [WHO (World Health Organization), 2014b; WHO (World Health Organization), 2014a]. Climate change can also worsen already existing socio-economic conditions such as livelihood 
and incomes for youths, which include losses of livelihood options and reduced income especially those involved in agriculture (Pereznieto et al., 2011).

The world's population is ageing, and by 2050 , over $21 \%$ of the global population will be 60 or over. The elderly have significantly higher mortality risk in extreme weather events resulting from increased susceptibility to diseases, reduced mobility and the effects of stresses on food and water availability (Fiberto et al., 2011; Help International, 2015). While in the event of climate related disasters, persons with disabilities may face added disadvantages in having their needs met and are more likely to be left behind during evacuation, have support networks disrupted, experience discrimination and gaps in access to services and resources during recovery and reconstruction (The Global Partnership for Disability and Development (GPDD) and The World Bank (Human Development Network - Social Protection/ Disability and Development Team, 2009). Similarly, indigenous communities are among the first to face the direct consequences of climate change, owing to their dependence upon, and close relationship with the environment and its resources. For example, rising temperatures, dune expansion, increased wind speeds and loss of vegetation are negatively impacting traditional cattle and goat farming practices of indigenous peoples in Africa's Kalahari Basin, who must now live around government-drilled bores to access water and depend on government support for their survival. (United Nations backgrounder, 2008). In Central Africa, up to $90 \%$ of Lake Chad has disappeared, which leaves nomadic indigenous groups particularly at risk (BBC report, 2018).

Societal and cultural norms compound climate change risks on women by virtue of their roles and duties, limitations in practicing survival skills. Oxfam (2005) reported that surviving men outnumbered women by almost 3:1 in Sri Lanka, Indonesia and India with similar patterns across the region in during floods because men were more likely to be able to swim, and women lost evacuation time looking after children and other relatives (Oxfam, 2005).

Thus, the magnitude of climate change impacts on a population is influenced by societal structures, gender, poverty, power and access to and control over resources. Additionally, climate change compounds resource scarcity and may intensify existing inequalities and result in greater fissures between communities and a rise in violence and conflict (Evans, 2010). Conversely, existing inequalities can also exacerbate individuals' vulnerability to the negative effects of climate change (Intergovernmental Panel on Climate Change [IPCC], 2007). The most vulnerable groups, by lacking a voice and influence in climate change policymaking, are therefore unlikely to receive the support they need as policies are less likely to account for their particular experiences (Polack 2008, p. 17), because of insufficient analysis of their specific vulnerability. In particular, the existence of gender inequality compounds women's vulnerability, resulting from the different positions of women and men have over the years been influenced by historical, religious, economic and cultural realities (Nelson, 2011).

\subsection{Climate change, gender equality and gender equity}

Gender equality refers to the equal rights, responsibilities and opportunities of women and men and girls and boys. This implies that the interests, needs and priorities of both, women and men are taken into consideration in development, recognizing their diversity. This is both, a human rights principle and a precondition for sustainable, people-centered development (adapted from UN Women). Before gender equality can be achieved, there is need to achieved equity among gender, which is the process of 
EFCC

3,1

6

being fair to both women and men (UNFPA, 2005). Equity can actually be a step towards equality. Gender equality and equity therefore emphasize the fact that access to opportunities and life changes should not be dependent on, nor should be constrained by sex.

Climate change affects the factors most essential to women's means of livelihood which include food, water, energy supply and health (AfDB, 2009a). This accounts for the variations in the physical and economic capacity of women and men to adequately cope with the effects of climate change. Gender equality is considered a core contributor to better development outcomes, including poverty reduction and increased sustainability (World Bank, 2012). Gender mainstreaming should therefore be an important factor in both mitigation and adaptation to ensure success and sustainability of projects on climate change (AfDB, 2009a). AFDB Africa Gender Equality Index 2015 measures gender equality across three separate dimensions: equality in economic opportunities, equality in human development and equality in law and institutions. It provides evidence on gender equality of 52 out of the 54 countries in Africa and was designed to measure gender inequality and promote development. Scores of this index range from 0 to 100 with 100 representing perfect gender equality and the scores of African countries range from 15.8 to 74.5, with an average score of 54.1 (African Development Bank Group, 2015). Similarly, and the recent 2017 Global Gender Gap Report examines the gap between women in four fundamental categories; economic participation and opportunity, education attainment, health and survival and political attainment. It focuses on measuring gaps rather than levels, by capturing gaps in outcome variables rather than gaps in input variables, and then ranks countries according to gender equality rather than women's empowerment (Figure 1 shows a regional gap index). A link between gender gap index and gender equality plans, actions and policies in the NDCs gives a confirmation of gender efforts by some African countries and also possible explanations as to why some countries have no gender equality actions, plans and policies in their NDCs.

The importance of taking into account gender equality in climate actions is recognized in the Paris Agreement, in the Preamble, as well as in Articles 7 and

Figure 1.

Summary of gender and climate change framework

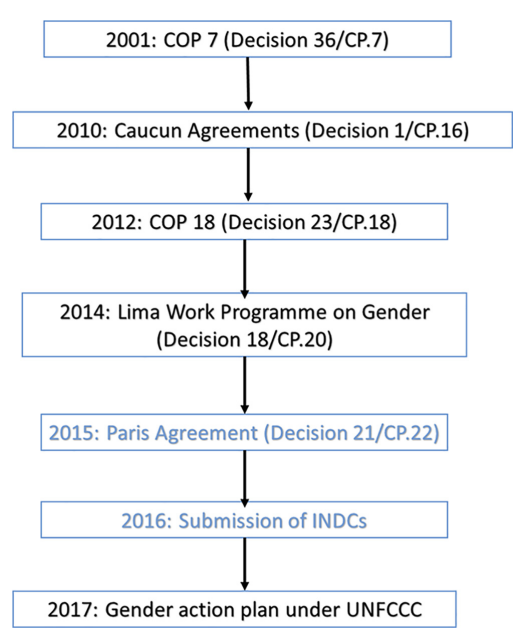


11 referring to adaptation actions and capacity development. Gender equality is one of the cross-cutting social development issues listed in the Paris Agreement Preamble.

Within the 2030 Agenda for sustainable development, gender equality and women's empowerment are both standalone goal and a critical cross-cutting component of the most of the SDG goals (Figure 2), and if effectively implemented, will be a milestone towards achieving gender equality. SDG 5 emphasizes the need to achieve gender equality and empower all women and girls. Therefore, promoting the economic empowerment of women is a critical catalyst for development, which will help boost a country's economic growth, promotes the socioeconomic development not only of women, but of the entire population and help reduce poverty (OECD, 2008; World Bank, 2006a).

\section{Main objective}

The main objective of this paper is to contribute towards amended integration of genderrelated issues into climate change policies and planning in support of the implementation of Africa's NDCs.

Specific Objectives

- disaggregation of climate risks and vulnerability on women in key sectors: Water, Energy Agriculture and Health sectors;

- orientating gender integration in the NDCs of African countries; and

- exploiting emerging opportunities for empowerment of women in the climate change scenario to give proper orientation for policy recommendations.

\section{Methodology}

The methodology involved a combination of desk research and quantitative and qualitative statistical analyses of the NDCs of African countries.

- The Desk Study involved the review of vast amount of literature on gender and climate change.

- Identification of the risks posed by climate change to women in different sectors (mention the sectors). Then using the Circos Software, the linkages and interlinkages between the risks were established.

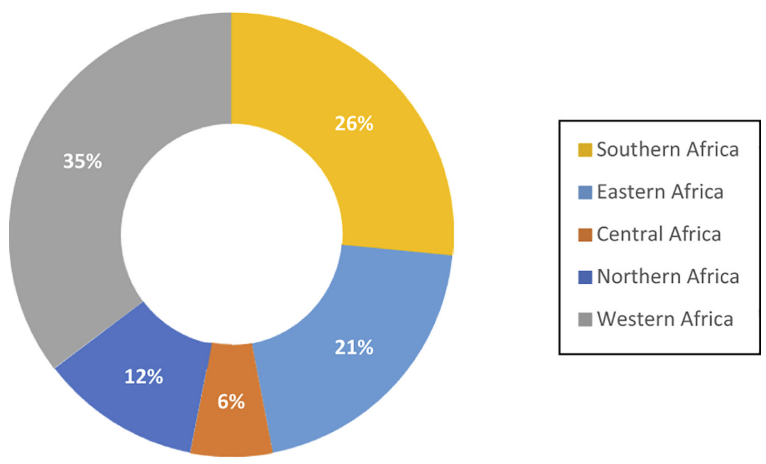

Source: Author, based on the Gender Gap report 2017

Figure 2. Gender gap index at regional levels 
EFCC

3,1

\section{8}

- Qualitative analysis, specifically diagnostic analytics of gender planning, actions and policies in NDCs of African countries was carried out. The gender plans, actions and policies were classified under mitigation, adaptation, gender equality and gender in climate change policy. These three broad topics incorporate all other aspects into a climate change gender-responsive narrative.

\section{Results}

5.1 Women and risks in key climate change affected sectors

This section looks at the risks faced by women in key sectors as understanding these risks and the linkages between them is key to better considerate inclusive adaptation and mitigation strategies.

The risks identified in water sector included water scarcity, poor water quality, increase incidence of floods, poor sanitation, conflicts and violence over water resources, diseases outbreak. In the agricultural sector, the risks include; droughts/dry spells, low agricultural productivity, loss of source of income/livelihood, conflicts and violence over land disputes, migration and in the risks in the health sector include diseases outbreak (such as cholera, typhoid, dysentery), heat stress. Figure 3 shows the linkages and interlinkages between some of these climatic risks. Droughts/dry spells for example leads

Figure 3.

Gender equality at the heart of many of the other SDGs

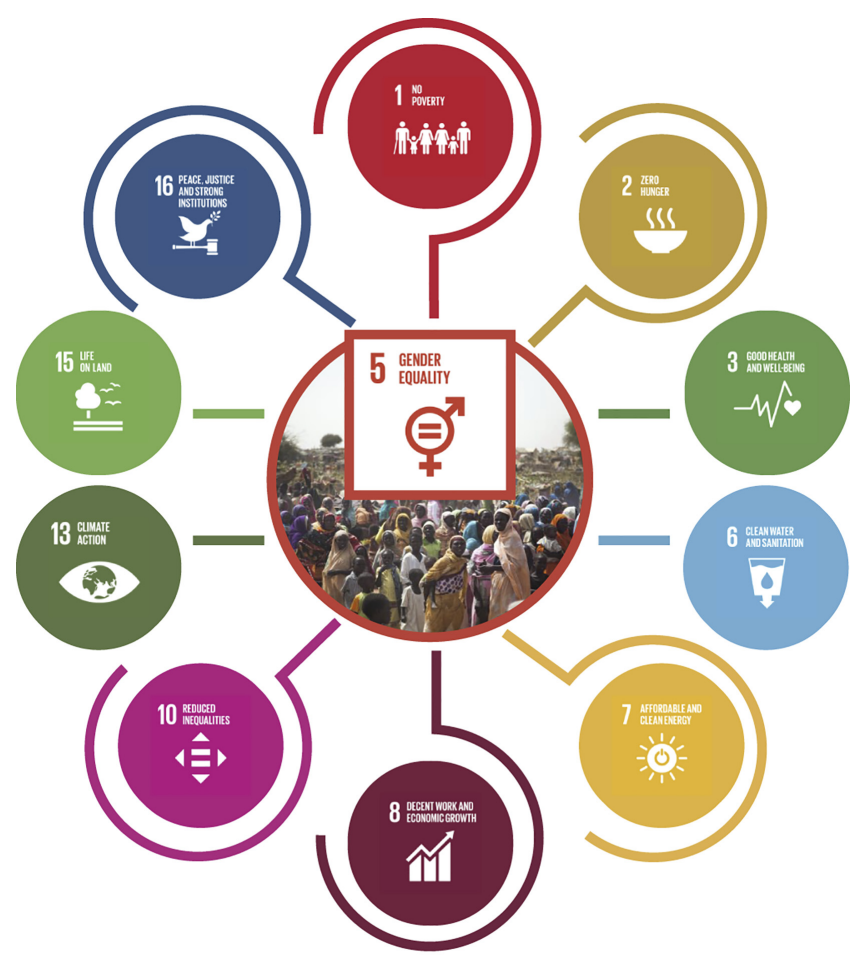

Source: Author, based on discussion in the text 
to water scarcity which affects agricultural productivity (both for irrigated and nonirrigated crops), which can lead to loss of income, migration. Water scarcity will lead to poor sanitation, which can cause serious bacterial diseases in women. Also, floods affect water quality, which leads to the prevalence of infectious diseases such as cholera, typhoid and also forced migration.

5.1.1 Water sector. The trend of climatic impacts over the years shows that the water sector in Africa will be one of the most affected by climate change. African countries have already shifted or will be shifting from water surplus to water scarcity between 1990 and 2025, and by 2030 up to 250 million people in Africa will be living in areas of high water stress, which is likely to displace up to 700 million people as conditions become increasingly unlivable (UNEP, 2002; FAO, 2013). Recent research in Mali records that during the dry season in rural areas water is 20-40 times more expensive than in major cities, leading to intra household rationing of supplies (Becerra et al., 2016). Women and girls are responsible for fetching portable water for the household (UN Women, 2014a, 2014b); therefore, the incidence of water scarcity means fetching water may involve great expense of time and energy for those who have no water sources in or near home. The time spent fetching water depends on aspects such as household size, distance, seasons and even income. Sorenson et al. (2011) demonstrate that women are the most common water fetchers $(58.6 \%)$ with nearly an hour per trip, followed by men $(30.4 \%)$, with water carrying that took less than $15 \mathrm{~min}$ and from an improved water source, and children $(9.1 \%)$. There are negative health aspects are associated with collecting water especially at long distances such long-term back injuries, spinal cord injuries and joint problems (Geere et al., 2010). A study by Graham et al. in 24 countries Sub-Saharan Africa, revealed that among households spending more than $30 \mathrm{~min}$ collecting water, adult females were the primary collectors of water, ranging from $46 \%$ in Liberia $(17,412$ Households) to $90 \%$ in Cote d'Ivoire (224,808 Households). Across all 24 countries, female children were more likely to be responsible for water collection than male children (62 vs 38\%, respectively) (Graham et al., 2016).

Water scarcity is linked to poor sanitation and personal hygiene for women, as water needs to be rationed for more important uses such as drinking and cooking. According to WHO, in 2012, water, sanitation and hygiene was responsible for 842,000 deaths from diarrhea, and $1.5 \%$ of the global burden of disease (World Health Organization, 2011). During the recent water scarcity crises in Cape Town, South Africa, it was reported that women had to stay for days without having a proper a shower, and toilets are not properly cleaned (BBC, 2018) which puts women at risk of contracting urinary tract infections. In Ethiopia, women and girls practice poor hygiene due to scarcity of water that leads to illnesses (CharityWater, 2012). The incidence and magnitude of floods is also likely to increase with climate change, which also puts women at high risk of vulnerability. The widespread flooding resulting from the overflowing of the Zambezi river in southern Africa affected thousands of people in Malawi, Mozambique and Zimbabwe, leading to crowded displacement camps with women and girls facing particularly dire circumstances, with many reporting lack of sanitary supplies and heightened threats of gender-based violence (UNFPA, 2015).

In the aftermath of a flooding disaster, women are faced with challenges such as gender specific work, for example carrying water, cooking for children and also taking care of those affected by floods, including children, those injured, the sick and the elderly, considerably increasing their emotional and material work load (Yonder et al., 2005). 
EFCC

3,1

5.1.2 Agricultural sector. Climatic changes will have serious impacts on agricultural production, and most women depend on agriculture for their livelihood. They comprise over $48 \%$ of the agricultural labor force in the developing world, almost $50 \%$ in Africa (FAO, 2018). Women farmers are more highly exposed to agricultural risks than men because they have fewer endowments and entitlements (World Bank, 2017). Women rarely have access and control over land and only $15 \%$ of land in subSaharan Africa is managed by women, when they do own or are leased land, their plots tend to be small and of poor quality (Denton, 2002; FAO, 2011). Factors such as cultural barriers (lack of traditional collateral such as land or property which is often registered in men's name), women's lower income levels relative to men, complicated administrative procedures, unsuitable loan sizes or interest rates and financial institutions' inability to design appropriate products and outreach strategies to reach women (Van Stavern, 2001; Adeniyi, 2010), limit women's access of loans and credits adding to their vulnerability in the agricultural sector. Male farmers in Ethiopia and Cameroon are more likely than women to use fertilizer to adapt to rainfall variability as women often lack sufficient capital (Alem et al., 2010; Molua, 2011).

With the vulnerability they already face, climate change will impact the source of livelihood for most rural women in Africa.

\section{Box 1. The case of Rural women of Cameroon.}

Agriculture in Cameroon just like most countries in Africa is the backbone of the economy. The cash crops produced are mainly; Coffee, Cocoa, Rubber, cotton, Banana, tea and the food crops include; rice, maize, cassava, yam, Irish potatoes, sweet potatoes, cocoyam, plantains, beans etc. In $2017,63.3 \%$ of women in Cameroon were employed in the agricultural sector (world Bank statistic, 2018). While men are mostly involved in commercial or cash crop production, women in the rural areas in Cameroon are mostly engaged in subsistence food production and supply about $90 \%$ of subsistence food for the population (Prakash, 2006). However, only 2 percent of women actually own land (Borgen Project, 2018). In all the stages of crop production (land preparation, harvesting and marketing), the workload doubles as they have to spend about 4 to 9 hours per day in farms especially households headed by women. This is coupled with other household chores which include; collection of fuelwood and water, cleaning, cooking, catering for children. Some of these women create farm groups "Njangis" where all members, go to each other's farms on a rotational basis to ease the workload. Sometimes, the "njangi's" are often accompanied with savings which help gather some cash for buying farm inputs or solve some family problems. Most of the rural women depend on the sales of their crops for survival especially women heading households with the entire responsibility of running the family resting on them. They have to provide food for the family, cater for the needs of the children (school fees, clothing, hospital bills etc.).

5.1.3 Health risks. In the high rainfall scenario, there is high incidence of infectious diseases such as malaria, cholera, dengue fever, typhoid onchocerciasis and 
schistosomiasis (de Souza et al., 2012). While in high temperatures scenario, warming and increased humidity have already contributed to observed increases in some health risks such as increased incidence of heat stroke, for example more elderly women than men died during the extreme heat wave in Europe in 2003, with France recording most deaths among elderly women (Pirard et al., 2005). Also, with low agricultural yields there are high chances of nutrient deficiencies, and undernutrition that affects pregnant and children the most. In extreme climatic situation, this can lead to hunger and famine.

\subsection{Gender in the nationally determined contributions of African countries}

In this section, the paper discusses gender in the NDCs of African countries. The discussion presents the findings of the evaluation of the NDCs of countries that discuss gender mainstreaming with respect to actions, policies and programmes for adaptation, mitigation and gender equality/gender in climate change policy. The countries include Angola, Benin, Burkina Faso, Burundi, Cameroon, Central African Republic, Chad, Comoros, Cote D'Ivoire, Democratic Republic of Congo, Eritrea, Ethiopia, Gambia, Ghana, Guinea, Kenya, Lesotho, Liberia, Malawi, Mali, Mauritius, Morocco, Niger, Nigeria, Senegal, Seychelles, Sierra Leone, Somalia, South Africa, South Sudan, Sudan, Swaziland, Uganda, Zambia and Zimbabwe. Based on these analyses, the following trends/observations emerged; 34 African countries out of the 40 that have submitted their NDCs referenced gender in their NDCs making a percentage of $85 \%$, an overall of $63 \%$ for all African countries mentioning gender in adaptation, mitigation or gender equality and gender climate change policy.

Liberia and Nigeria have the highest number ongoing or planned actions in adaptation, mitigation, gender equality and gender in climate change policy. Angola, Burundi, Central African Republic, Chad, DRC, Ethiopia, Guinea, Senegal, Sierra Leone, South Africa and Swaziland have one action only either in Adaptation, mitigation or gender equality/gender in climate change policy (Figure 4).

As shown in Figure 5, the country level analysis on gender integration in the NDCs revealed that 56 and $20 \%$ actions or programs in mitigation and adaptation, respectively, involving gender are being planned or are already being implemented. While there are already existing or plans (24\%) for strategies, policies on gender equality or gender in climate change policy.

Most countries made general gender actions without specific sectorial differentiation in their gender actions. Total number of actions in water sector is $2(6 \%)$, in the energy sector there are ten actions (32\%), Agriculture $11(36 \%)$ and health $8(26 \%)$ (Figure 6) (Figure 7).

\section{Box 2. Water sector-Actions in Cameroon and Mali.}

A project in Mali plans for the capturing and storage of rainwater to contribute to universal access to drinking water and access to water for other uses, through the creation of 20 drinking water supply systems and 200 surface water catchment and surface water benefit of 75,000 rural households especially men and women In Cameroon, there will be strengthening and securing of access to water resources and sanitation services in a context of climate change, with special emphasis on the use of surface and ground water by women. This will include management of surface water and groundwater, protection of the spring heads; fixing of banks and floors. 


\section{EFCC 3,1}

\section{2}

Figure 4.

Categorizing the linkages and interlinkages of climate risks faced by women

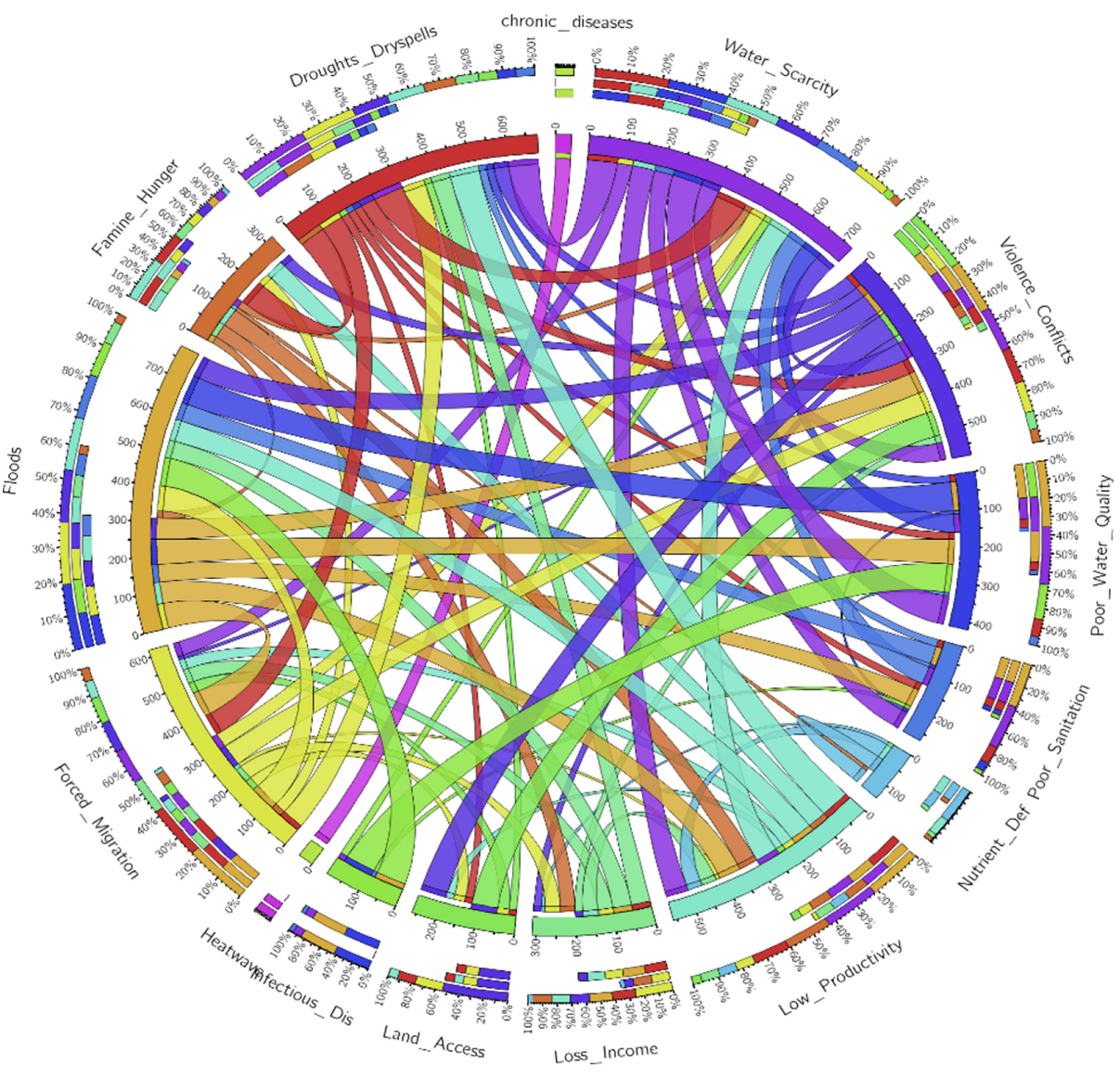

Box 3. Energy Sector- Senegal, Eritrea, Lesotho.

Senegal is undertaking the production of electricity from biomass and waste, in order to provide for the use of modern forms of energy in homes thus reducing the workload of women and contributing to the improvement of school performance of children. While the government of Eritrea has already taken concrete measures to introduce energy saving cooking stoves for rural households. These stoves have efficiency of about $26 \%$ compared to the traditional ones with $10 \%$. Besides reducing the pressure on the forest resources, the advantages of these stoves lie in the use of waste biomass as in securing the health and wellbeing of women and children. Lesotho's rural electrification programme will improve access to new information and communication technologies and energy equipment and alleviation of women's domestic duties. Through its Global Alliance for Clean Cook-stoves: it will create a market for clean and efficient household cooking solutions in order to save lives, improve livelihoods, empower women, and protect the environment 


\section{Box 4. Agricultural Sector- Cote D’Ivoire, Benin, Morocco.}

In the agricultural sector, Cote D'Ivoire plans to promote women's access to rural land; taking into account the gender aspect (women), and also capacity building of actors (especially women, farmers, etc.); focuses on new technical routes in the context of intensified and sustainable production methods. Benin has specific projects relating to gender in the agricultural sector which include: rehabilitation of hydro-agricultural development of 300ha of vegetable gardens for women and improving access to professional knowledge and technology, innovations for men and Women $(50 \%)$ increase in current productivity levels by 2025 . Morocco unconditionally will revegetate bare or eroded lands with 128,600 hectares of cacti in drylands to enhance smallholder farmers and women's cooperative income. The implementation Cost is estimated at 91 USD in millions with a total emission reduction potential between 2020-2030 of 7.892 MT CO2e

\section{Box 5. Health Sector - Liberia. \\ Liberia plans to integrate climate change considerations into existing health policies and strategies, taking into account gender-differentiated impacts and responses. Also, Angola, Benin, Burkina Faso, Eritrea, Niger, Senegal link the use of clean and improve cooking stoves to improving health conditions for women by reducing in-door pollution from the use of the traditional cooking stoves.}

\subsubsection{Regional analysis of gender mainstreaming in the Nationally Determined Contribution.} West Africa has the highest number of actions on gender (32) in their NDCs making $41 \%$, closely followed Eastern Africa with a total of 23 actions (30\%). Southern Africa has $12(15 \%)$, while Central Africa and North Africa have 6 and 5 actions, respectively, making 8 and $6 \% 3 \%$, as shown in Figure 4 .

The above analysis is quite similar with the 2017 gender gap report where West Africa tops the chart with 35\%. However, Southern Africa has 26\% and East Africa, $21 \%$. North Africa has $12 \%$ and central Africa 6\% (Figure 8).

5.2.2 Empowerment of women to address climate change in Africa. Women are integral part to the solution towards tackling climate change, and empowering them economically, socially and politically is an astute strategy. Though gender equality and women's empowerment is slowly gaining recognition, women and girls continue to suffer discrimination, and often limited to the periphery of climate solutions. Important aspects of empowerment for women include access to resources such as land, loans and credits, education, technology and Climate Information Services (CIS). Access to weather and climate information and services is uneven between men and women. Limited access to information and services contributes to women's vulnerability and affects their ability to adapt. For example, men in Senegal and Uganda tend to have access to better weather information than women that can be 


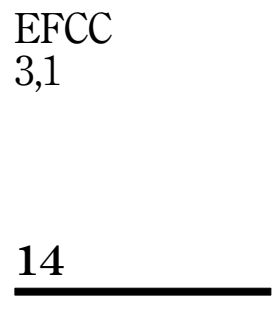

Figure 5.

Gender actions in the NDCsSource: Author based on Analysis from the NDCs

\section{Figure 6.}

Percentage distribution of gender actions in different areas of interventionSource: Author based on Analysis from the NDCs

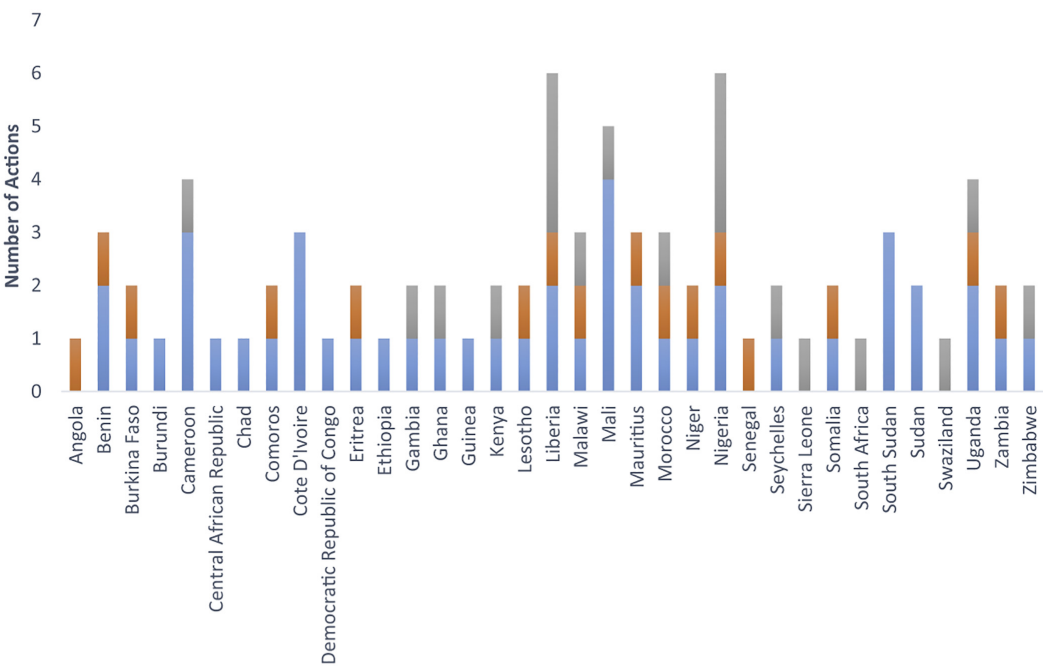

Countries

$$
\text { adaptation Mitigation } \quad \text { Gender equality/Gender in Climate Change policy }
$$

Source: Author based on Analysis from the NDCs adaptation Mitigation $\square$ Gender equality/Gender in Climate Change policy

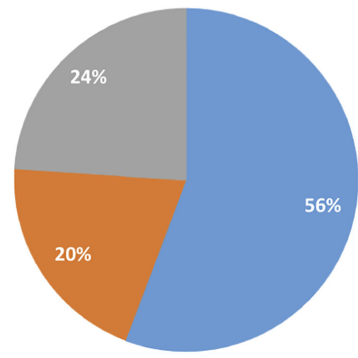

Source: Author based on Analysis from the NDCs

used to modify production practices (Twyman et al., 2014). By identifying obstacles in accessing these critical resources, actions towards improving access can be made which will be a step towards enabling inclusive environment for adaptation and mitigation. Including accelerating access to new technologies such as energy efficient stoves, renewable energy system. 


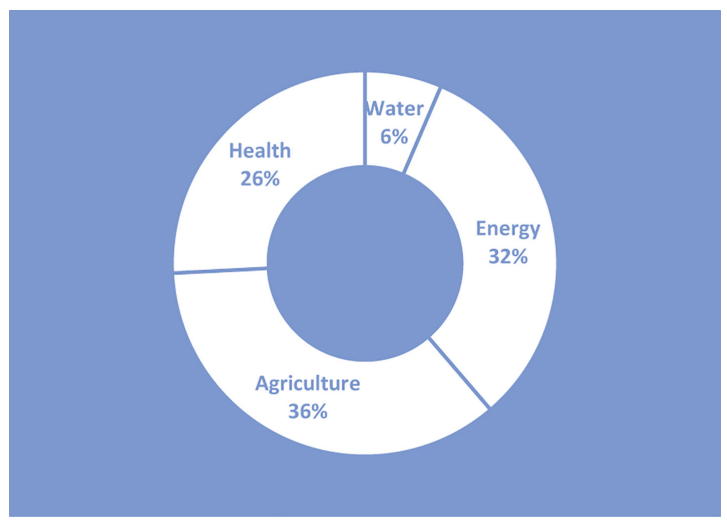

Source: Author based on Analysis from the NDCs

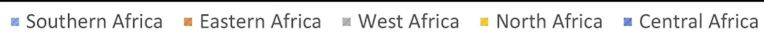

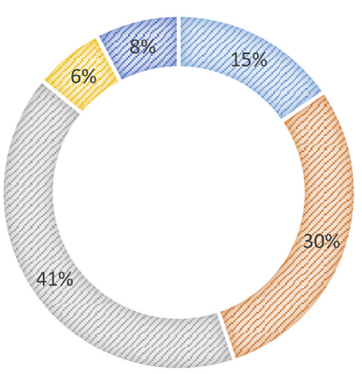

Also, awareness, sensitizations and trainings on the various facets of climate change; the risks, consequences, possible sustainable resolutions (Adaptation and mitigation strategies). Specifically, need for training on adaptation measures that address their vulnerability, such as alternative methods of cultivation, clean energy, more efficient use of water for domestic and agricultural purposes, and their basic rights especially with regards to land and ownership. Credit and skills-development programs, use of climate information systems, trade and value addition, decision-making will also reduce vulnerabilities to climate change.

Capitalizing on empowering women in decision making or what can be termed "political empowerment" is necessary at all levels of climate negotiations whether at local, regional or international levels. This can be done by recruiting more women at the negotiating table, creating climate leadership fellowships and scholarships etc. In 2017, at COP 23, women made up less than $25 \%$ of participants from African countries (Author: from the participant list of COP 23). In their Nationally Determined Contributions, some African countries - Angola, Comoros, Liberia, Mauritius - made reference to gender in decision-making for in their mitigation and adaptation actions.

By ensuring proper recognition of the environmental risks women face, the key role they can play in climate change mitigation and adaptation, provide opportunities for them to take
Figure 7.

Gender actions in the water, energy, agriculture and health sectors

Figure 8.

Regional distribution gender mainstreaming in the NDCs 
EFCC 3,1

an active role in climate change. By creating leadership trainings and gender-sensitive leadership pathways, foster inclusivity in leadership, civic engagement and decision-making in public and private spheres, and ensuring recognition of women in decision-making capacities, will be a step towards achieving future multi-faceted goals set by African countries and the international community.

5.2.3 Exploiting emerging opportunities for women empowerment in the climate change scenario. The potential of and for women with regard to climate change response is seldom recognized. Because the effects of climate change are different for women and men, their coping responses also tend to be different. These coping responses, create great opportunities for them that could be explored and can lead to their empowerment. Women have lots of potential as agents of change for climate adaptation and mitigation, which still remains very much untapped. For example, Women are seen as repositories of knowledge about crops and climate, the environment, natural resources, food preservation techniques, etc. by men (Petrie, 2011). A good example of how climate change can spur agricultural innovation in women comes from Cameroon where women, after experiencing high post-harvest losses because of heavy rainfall, harnessed their indigenous knowledge by turning crops into processed foods that lasted longer and had a better market value (Fordham et al., 2001). Due to their close interaction with nature, women possess appropriate knowledge about the environment and resource conservation which can be tapped to fit in the climate information systems, essential for climate adaptation and mitigation. As such, technological developments related to climate change should therefore take into account women's roles, and make full use of their knowledge and expertise, including indigenous knowledge and traditional practices. Their involvement in the development of new technologies can ensure that they are user-friendly, affordable, effective and sustainable.

Women provide environmental services such as reforestation and afforestation, which are often not remunerated. There are opportunities to recognize these contributions in various climate change interventions such as the CDM and REDD+. The Clean Development Mechanism (CDM), Emissions Trading, Reduced Emission from Deforestation and Degradation (REDD+) as well as numerous bilateral and multilateral climate funds (climate finance), could be options for compensation and support for these services [GTZ Programme Promoting Gender Equality and Women's Rights (2009)].

The clean and efficient stoves is a technology that will not only prevent respiratory diseases that have plagued women especially in Sub Saharan Africa but can empower them. The use of solid biomass in traditional stoves is not per se directly a result of climate change; however, the empowerment of women can actually be heightened with the use of efficient and clean cooking stoves. It should be noted that burning of solid biomass creates noxious fumes, which has been the cause of close to 2.8 million premature deaths annually (IEA, 2017). Moreover, less time will be spent fetching fuelwood, which could be directed to engage in income generating activities or other activities that empower them. Nearly all rural households in Africa use fuelwood for cooking (more than $90 \%$ in 25 countries in Sub Saharan Africa, IEA, 2017) and with increasing fuelwood scarcity, women are spending much time in fuelwood gathering as part of their daily tasking. Also, collecting fuelwood, by themselves, present a threat to their security, for example fuelwood scarcity will mean going to faraway places, which puts them at risk of rape.

\section{Conclusion}

Climate change is a serious threat to humanity and views from mostly those affected indicates that there is still a big disconnect between the ambitious agendas set by various stakeholders involved (International organizations, governments and regional organizations), and the real grassroots initiatives, actions and programs being 
implemented in the ground. There is also inarguably increasing evidence that climate change is amplifying gender inequality, the vulnerability of women and children, consequently a serious barrier to the achievement of the Paris Agreement, UN 2030 Sustainable development goals, the 2063 Africa Union Agenda.

African countries are making efforts towards integrating gender equality in their fight against by incorporating gender perspectives into their national policies, action plans and other measures on sustainable development and climate change. However, they need to carry out systematic gender analysis; collecting and using sexdisaggregated data; establishing gender-sensitive benchmarks and indicators; and developing practical tools to support increased attention to gender perspectives. In particular, they need to:

- create inter-sectoral and inter-ministerial synergies especially in building effective climate land energy water strategies (CLEWs);

- implement effective water resource management to minimize situations of water scarcity;

- build and support capacity development at all levels, while ensuring that participation is gender-balanced especially in the of uptake of Climate Information Systems (CIS);

- harness information from the coping strategies of men and women to build practical, inclusive adaptation strategies;

- consult with various stakeholders including youth and women groups, and other vulnerable groups on strategies of implementation; and

- develop methods of compensation for environmental services.

\section{References}

Adeniyi, L. (2010), "Women farmer's and agriculture growth: challenge and perspective for Africa face the economic crisis", available at: https://ageconsearch.umn.edu/bitstream/97062/2/92.\% 20Women \%20labor \%20and\%20agriculture\%20growth.pdf.

African Development Bank Group (2015), Empowering African Women: An Agenda for Action: African Gender Equality Index, African Development Bank Group.

Alem, Y., Bezabih, M., Kassie, M. and Zikhali, P. (2010), "Does fertilizer use respond to rainfall variability? Panel data evidence from Ethiopia”, Agricultural Economics, Vol. 41 No. 2, pp. 165-175.

BBC (2018), “Cape town water crisis: 'my wife doesn't shower any more”, available at: www.bbc.com/ news/world-africa-42787773.

BBC report (2018), "Climate change 'impacts women more than men”, available at: www.bbc.com/ news/science-environment-43294221.

Becerra, S., Saqalli, M., Gangneron, F. and Dia, A.H. (2016), "Everyday vulnerabilities and 'social dispositions' in the Malian Sahel, an indication for evaluating future adaptability to water crises?”, Regional Environmental Change, Vol. 16 No. 5, pp. 1253-1265.

CharityWater (2012), “Why water?' charity: water. water, n.d”, Web. 25 July 2012, available at: www. charitywater.org/whywater.www.smith.edu/health/documents/Madison.pdf.

Davis, I., et al. (2005), “Tsunami, gender, and recovery”, Special Issue for International Day for Disaster Risk Reduction, All India Disaster Mitigation Institute, Gujarat.

de Souza, P.N., Dziedzom, K., Owusu, M. and Wilson, D. (2012), Impact of Climate Change on the Geographic Scope of Diseases, doi: 10.5772/50646. 
EFCC 3,1

Denton, F. (2002), “Climate change vulnerability, impacts, and adaptation: why does gender matter?", Gender and Development, Vol. 10 No. 2.

Evans, A. (2010), "Resource scarcity, climate change and the risk of violent conflict", WORLD DEVELOPMENT REPORT 2011 BACKGROUND PAPER, available at: http://siteresources. worldbank.org/EXTWDR2011/Resources/6406082-1283882418764/WDR_Background_Paper_ Evans.pdf.

FAO (2011), The State of Food and Agriculture: women in Agriculture Closing the Gender Gap for Development, Food and Agriculture Organization, Rome, Italy.

FAO (2013), Based on Data from Post-Disaster Needs Assessments, 2003-2013, FAO.

FAO (2013), "Hot issues: water scarcity", available at: www.fao.org/nr/water/issues/scarcity.html., Google Scholar.

FAO (2011), "The role of women in agriculture", ESA Working Paper No. 11-02 March 2011, available at: www.fao.org/docrep/013/am307e/am307e00.pdf.

Graham, J.P., Hirai, M. and Kim3, S.-S. (2016), An Analysis of Water Collection Labor among Women and Children in 24 Sub-Saharan African Countries, Published online 2016 Jun 1, doi: 10.1371/ journal.pone.0155981.

Help International (2015), Climate Change in an Ageing World, Help International.

Intergovernmental Panel on Climate Change (2007), "Synthesis report: an assessment of the intergovernmental panel on climate change", Retrieved October 24, 2008, available at: www. ipcc.ch/ipccreports/ar4-syr.htm.

McKinsey Global Institute (2015), “The power of parity: how advancing women's equality can add $\$ 12$ trillion to global growth", available at: www.mckinsey.com/ /media/McKinsey/Featured $\%$ 20Insights/Employment \% 20and\%20Growth/How \%20advancing $\% 20$ womens $\%$ 20equality $\%$ 20can $\% 20$ add $\% 2012 \%$ 20trillion $\% 20$ to $\% 20$ global $\%$ 20growth/MGI $\% 20$ Power $\% 20$ of $\%$ 20parity_Executive\%20summary_September\%202015.ashx.

Molua, E.L. (2011), "Farm income, gender differentials and climate risk in Cameroon: typology of male and female adaptation options across agroecologies", Sustainability Science, Vol. 6 No. 1, pp. 21-35.

Mwebaza, R. and Kotzé, L.J. (2009), Environmental Governance and Climate Change in Africa Legal Perspectives, Monograph 167. Institute for Security Studies.

Nazrul Islam, S. and Winkel, J. (2017), “Climate change and social inequality”, DESA Working Paper No. 152 ST/ESA/2017/DWP/152, available at: www.un.org/esa/desa/papers/2017/wp152_ 2017.pdf.

Nelson, V. (2011), Gender, Generations, Social Protection and Climate Change, A thematic View.

Neumayer and Plumper (2007), The Gendered Nature of Natural Disasters: The Impact of Catastrophic Events on the Gender Gap in Life Expectancy, 1981-2002, Neumayer and Plumper.

Niang, I., Ruppel, O.C., Abdrabo, M.A., Essel, A., Lennard, C., Padgham, J. and Urquhart, P. (2014), "Africa", Climate Change 2014: Impacts, Adaptation, and Vulnerability. Part B: Regional Aspects. Contribution of Working Group II to the Fifth Assessment Report of the Intergovernmental Panel on Climate Change, Cambridge University Press, Cambridge.

OECD (2008), Gender and Sustainable Development. Maximising the Economic, Social and Environmental Role of Women, OECD.

Pereznieto, P. et al. (2011), Youth Vulnerabilities and Adaptation Exploring the Impact of Macro-Level Shocks on Youth: $3 F$ Crisis and Climate Change in Ghana, Mozambique and Vietnam, Overseas development Institute.

Polack, E. (2008), "A right to adaptation: Securing the participation of marginalized groups", IDS Bulletin, Vol. 39 No. 4, pp. 16-22.

Porter, J.R., et al. (2014), "Chapter 7. Food security and food production systems", Climate Change 2014: Impacts, Adaptation and Vulnerability. Working Group II Contribution to the IPCC 5th Assessment Report, Geneva, Switzerland. 
Sorenson, S.B., Morssink, C. and Abril Campos, P. (2011), "Safe access to safe water in low income countries: water fetching in current times", Social Science and Medicine, Vol. 72 No. 9, pp. 1522-1526, doi: 10.1016/j.socscimed.2011.03.010.

The Global Partnership for Disability and Development (GPDD) and The World Bank (Human Development Network - Social Protection/Disability and Development Team (2009), "The impact of climate change on people with disabilities", available at: www.ucl.ac.uk/lc-ccr/centrepublications/ staffpublications/Impact_of_Climate_Change_on_Disability-Report-2010.pdf.

Twyman, J. et al. (2014), Adaptation Actions in Africa: evidence That Gender Matters, CGIAR Research Program on Climate Change, Agriculture and Food Security.

UN Women (2013), "Climate change, disasters and gender-based violence in the pacific", available at: www.uncclearn.org/sites/default/files/inventory/unwomen701.pdf.

UN Women (2014a), "Why is climate change a gender issue?", available at: www.uncclearn.org/sites/ default/files/inventory/unwomen704.pdf.

UN Women (2014b), "Collecting and carrying water, burdensome reality for women", available at: www.unwomen.org/en/news/stories/2014/3/collecting-and-carrying-water-burdensome-realityfor-women.

UNECA, AU, AFDB, UNDP (2016), MDGs to Agenda 2063/SDGs Transition Report 2016: Towards an Integrated and Coherent Approach to Sustainable Development in Africa, UNECA, AU, AFDB, UNDP.

UNEP (2002), "Vital climate graphics, Africa”, UN Environmental Programme, Nairobi, available at: www.grida.no/publications/vg/africa/., Google Scholar.

UNFPA (2015), "Floods hit hundreds of thousands in Southern Africa; women and girls most vulnerable", available at: www.unfpa.org/news/floods-hit-hundreds-thousands-southern-africawomen-and-girls-most-vulnerable.

United Nations Children's Fund (UNICEF) (2015), "The impact of climate change on children. Van Stavern, I. 2001 "Gender biases in finance", Gender and Development, Vol. 9 No. 1, pp. 9-17, Money (Mar., 2001).

WHO (World Health Organization) (2014a), Household Air Pollution and Health, Fact sheet No. 292. (accessed 11/11/2015).

WHO (World Health Organization) (2014b), Burden of Disease from Household Air Pollution for 2012, (accessed 11/11/2015).

World Bank (2006a), "Gender equality as smart economics: a world bank group gender action plan (fiscal years 2007-10)", available at: http://siteresources.worldbank.org/INTGENDER/ Resources/GAPNov2.pdf. (accessed 26.01.2010).

World Bank (2017), "Gender and agricultural risk: a gendered approach to agricultural risk assessments and management strategies. Agriculture global practice discussion paper", available at: https://borgenproject.org/land-rights-limit-cameroons-gender-equality59245/.

World Health Organization (2011), "Indoor air pollution and health", Fact sheet 292, available at: www.who.int/mediacentre/factsheets/fs292/en/.).

Yonder, A. Sengul, A. and Prema, G. (2005), "Women's participation in disaster relief and recovery", available at: http://americalatinagenera.org/ciclonew/E4D9_Womens_participation.pdf.

Zukang, S. (2008), "Statement by sha zukang, under-Secretary-General for economic and social affairs", ECOSOC Special Event on "Achieving the MDGs and Coping with the Challenges of Climate Change", 2 May 2008, UN Office of the Under-Secretary-General ECOSOC, New York, NY.

\section{Further reading}

available at: www.fao.org/gender/background/en/.

available at: www.fao.org/news/story/en/item/345727/icode/.

available at: https:/unfccc.int/topics/gender/the-big-picture/introduction-to-gender-and-climate-change. 
EFCC 3,1

available at: www.unfpa.org/resources/frequently-asked-questions-about-gender-equality.

available at: www.worldvision.com.au/global-issues/work-we-do/climate-change/climate-change-theeffects-on-children.

available at: www.un.org/en/events/indigenousday/pdf/Backgrounder_ClimateChange_FINAL.pdf.

available at: www.unfpa.org/resources/frequently-asked-questions-about-gender-equality.

Climate change and indigenous peoples (2008), "United nations backgrounder", available at: www.un. org/en/events/indigenousday/pdf/Backgrounder_ClimateChange_FINAL.pdf.

Dasgupta, P., Morton, J.F., Dodman, D., Karapinar, B., Meza, F., Rivera-Ferre, M.G., Sarr, A.T. and Vincent, K.E. (2014), "Rural areas", in: Field, C.B., Barros, V.R. Dokken, D.J. Mach, K.J. Mastrandrea, M.D. Bilir, T.E. Chatterjee, M. Ebi, K.L. Estrada, Y.O. Genova, R.C. Girma, B. Kissel, E.S. Levy, A.N. MacCracken, S. Mastrandrea, P.R. and White, L.L. (Eds), Climate Change 2014: Impacts, Adaptation, and Vulnerability. Part A: Global and Sectoral Aspects. Contribution of Working Group II to the Fifth Assessment Report of the Intergovernmental Panel on Climate Change, Cambridge University Press, Cambridge, United Kingdom and New York, NY, pp. 613-657.

Desanker, P. C, M. et al. (2001), "Working group II: impacts, adaptation and vulnerability”, Chapter 10, Africa, available at: www.ipcc.ch/ipccreports/tar/wg2/index.php?idp $=377$.

Center for Public Health and Climate Change at the Public Health Institute (PHI), the World Food Programme (WFP), the UN Standing Committee on Nutrition (UNSCN) and Action Against Hunger (ACF) Enhancing Women's Leadership to Address the Challenges of Climate Change on Nutrition Security and Health.

Filberto, D., et. al. (2011), “Older people and climate change: vulnerability and health effects”, Journal of the American Society on Aging, Vol. 2011.

Giovarelli, R., Beatrice, W. and Leslie, H. (2013), Land Tenure, Property Rights, and Gender Challenges and Approaches for Strengthening Women's Land Tenure and Property Rights, USAID, July 2013. Web. 13 Apr. 2016.

Global Gender and Climate Change Alliance (GGCA) Facts from Gender and Climate Change: A Closer Look at Existing Evidence, Global Gender and Climate Change Alliance (GGCA).

Hardoy, J. and Pandiella, G. (2009), "Urban poverty and vulnerability to climate change in Latin America”, Environment and Urbanization, Vol. 21 No. 1, pp. 203-224.

Jo-Anne L Geere, Paul R Hunter, Paul Jagals (2010), "Domestic water carrying and its implications for health: a review and mixed methods pilot study in Limpopo province", South Africa, Environmental Health 2010, 9:52, available at: www.ehjournal.net/content/9/1/52.

Laurent, T. and Magali, B. (2006), "The mortality impact of the august 2003 heat wave in France", Paper prepared for presentation at the 2006 Population of America Association Meeting, Los Angeles, March 30-April 1st.

Mitlin, D. and Satterthwaite, D. (2013), Urban Poverty in the Global South: Scale and Nature, Routledge, Abingdon, Oxon, UK and New York, NY, p. 354.

Kyung, W-K. (2008), "Deputy high commissioner for human rights, OHCHR. 'climate change, migration and human rights", Keynote address at Conference on Climate Change and Migration: Addressing Vulnerabilities and Harnessing Opportunities, Geneva, available at: www.unhchr.ch/huricane/huricane.nsf/view01/BA5B630BFFAD7FC1C12573F600386398? opendocument.

Ngozi Akosa, T. and Oluyide, A. (2010), Gender and Climate Change - Case Study of Oko Agbon Odooyi Community, Case Study Series 1, Centre for 21st Century, Lagos.

Serdeczny, O., et al. (2016), "Climate change impacts in Sub-Saharan Africa: from physical changes to their social repercussions", Regional Environmental Change, Vol. 17 No. 6, doi: 10.1007/s10113015-0910-2.

Revi, A., et al. (2014), "Urban areas", in Field, C.B., Barros, V.R. Dokken, D.J. Mach, K.J. Mastrandrea, M.D. Bilir, T.E. Chatterjee, M. Ebi, K.L. Estrada, Y.O. Genova, R.C. Girma, B. 
Kissel, E.S. Levy, A.N. MacCracken, S. Mastrandrea, P.R. and White, L.L. (Eds), Climate Change 2014: Impacts, Adaptation, and Vulnerability. Part A: Global and Sectoral Aspects. Contribution of Working Group II to the Fifth Assessment Report of the Intergovernmental Panel on Climate Change, Cambridge University Press, Cambridge, United Kingdom and New York, NY, pp. 535-612.

Rural Development Institute (2009), "Secure land rights: the key to building a better, safer world: 2009 annual report", available at: www.landesa.org/wp-content/uploads/2011/02/2009_Annual_ Report.pdf., on November 2011.

Tatiana, D. Strengthen Women's Political Participation and Decision-Making Power, Women Deliver.

The Global Gender Gap Report (2017), available at: www3.weforum.org/docs/WEF_GGGR_ 2017.pdf.

UN Chief Executives Board (CEB) (2007), "Coordinated UN system action on climate change", United Nations, available at: www.uneca.org/eca_programmes/sdd/events/climate/CEBClimate.pdf.

UNDESA Population Division (2015), World Population Prospects: The 2015 Revision, UNDESA Population Division.

UNICEF (2012), "Progress in drinking water and sanitation. 2012 update", available at: www.unicef. org/media/files/JMPreport2012.pdf.

Women, Natural Resource Management, and Poverty (2010), A Review of Issues and Opportunities, New Course. 2010.

United Nations Permanent Forum on Indigenous people available at: www.un.org/esa/socdev/ unpfii/. 


\section{EFCC \\ 3,1}

Appendix

\begin{tabular}{|c|c|c|c|}
\hline \multirow[b]{4}{*}{22} & Country & Rank & Remarks \\
\hline & Liberia & 1 & Ranks 107 in the global gender gap Index 2017 \\
\hline & Nigeria & 1 & Ranks 122 in the global gender gap Index 2017 \\
\hline & Mali & 2 & Ranks 139 in the global gender gap Index 2017 \\
\hline & Uganda & 3 & Ranks 45 in the global gender gap Index 2017 \\
\hline & Cameroon & 3 & Ranks 87 in the global gender gap Index 2017 \\
\hline & Benin & 4 & Ranks 116 in the global gender gap Index 2017 \\
\hline & Cote D'Ivoire & 4 & Ranks 133 in the global gender gap Index 2017 \\
\hline & Malawi & 4 & Ranks 101 in the global gender gap Index 2017 \\
\hline & Mauritius & 4 & Ranks 112 in the global gender gap Index 2017 \\
\hline & Morocco & 4 & Ranks 136 in the global gender gap Index 2017 \\
\hline & South Sudan & 4 & No ranking in the global gender gap Index 2017 \\
\hline & Burkina Faso & 5 & Ranks 121 in the global gender gap Index 2017 \\
\hline & Comoros & 5 & No ranking in the global gender gap Index 2017 \\
\hline & Eritrea & 5 & No ranking in the global gender gap Index 2017 \\
\hline & The Gambia & 5 & Ranks 119 in the global gender gap Index 2017 \\
\hline & Ghana & 5 & Ranks 72 in the global gender gap Index 2017 \\
\hline & Kenya & 5 & Ranks 76 in the global gender gap Index 2017 \\
\hline & Lesotho & 5 & Ranks 73 in the global gender gap Index 2017 \\
\hline & Niger & 5 & No ranking in the global gender gap Index 2017 \\
\hline & Seychelles & 5 & No ranking in the global gender gap Index 2017 \\
\hline & Somalia & 5 & No ranking in the global gender gap Index 2017 \\
\hline & Sudan & 5 & No ranking in the global gender gap Index 2017 \\
\hline & Zambia & 5 & No ranking in the global gender gap Index 2017 \\
\hline & Zimbabwe & 5 & Ranks 50 in the global gender gap Index 2017 \\
\hline & Angola & 6 & Ranks 123 in the global gender gap Index 2017 \\
\hline & Burundi & 6 & Ranks 22 in the global gender gap Index 2017 \\
\hline & Ethiopia & 6 & Ranks 115 in the global gender gap Index 2017 \\
\hline & South Africa & 6 & Ranks 19 in the global gender gap Index 2017 \\
\hline & Swaziland & 6 & Ranks 105 in the global gender gap Index 2017 \\
\hline & Central African Republic & 6 & No ranking in the global gender gap Index 2017 \\
\hline & Chad & 6 & Ranks 141 in the global gender gap Index 2017 \\
\hline Ranking African & Democratic Republic of Congo & 6 & No ranking in the global gender gap Index 2017 \\
\hline Countries According to & Guinea & 6 & Ranks 113 in the global gender gap Index 2017 \\
\hline Gender Integration in & Senegal & 6 & Ranks 91 in the global gender gap Index 2017 \\
\hline the NDCs & Sierra Leone & 6 & No ranking in the global gender gap Index 2017 \\
\hline
\end{tabular}

\section{Corresponding author}

Charlotte Remteng can be contacted at: ckongnyuy2002@yahoo.fr

For instructions on how to order reprints of this article, please visit our website:

www.emeraldgrouppublishing.com/licensing/reprints.htm

Or contact us for further details: permissions@emeraldinsight.com 